\title{
A Beacon of Hope in Islamic Moral Values towards Sustainable Restructuring of Nigeria as a Nation
}

\author{
SALAHUDEEN Abdul Hameed
}

\begin{abstract}
There have been serious agitations from different quarters or sections of Nigerians calling for restructuring of Nigeria. It is believed that restructuring would engender good and responsible governance, desired development, peace and tranquility.

The attention has been focused on the amendment of the 1999 Federal Constitution of Nigeria to achieve the inevitable and desired change and reform towards the existence of Nigeria as a national entity while some are of the view that the socio-political problems Nigeria encounters have nothing to do with the structure of the Constitution itself but the oroblems are enshrined in the operators of the constitution.

This paper presents the picture that the answer to the restructuring question lies in collective sel-examination, fundamental change of attitude and public spirited approach to public administration by the operators of the constitution. This can be achieved, ensured and enhanced through Islamic moral ettiquettes and values.
\end{abstract}

Keywords — Islamic Moral Values, Restructuring of Nigeria.

\section{INTRODUCTION}

The word 'restructuring' is suggestive of lacuna, inadequacies, lopsidedness, discripancies, irrelevancies and problems all of which serve as impediments or forces jostling against the achievement of healthy state of Nigeria as a nation. Our polity and social system are beclouded with upheavals. The economy of nation is in shamble, the security system are beclouded with upheavals. The economy of the nation is in shamble, the security of the country worsens on daily basis, poverty is on the high increase, rather than creating jobs, Nigerians are fast loosing their jobs at the instance of poor governance bad leadership.

Our institution and system I Nigeria, no doubt, are in a bad and corrupt state against the mind-set of the founding fathers of Nigeria as a nation. Hence, the call and agitation for restructuring from different quarters, is justified so that Nigeria as a national entity, great nation among committee of nations and giant of Africa would be sustained. To achieve viable restructuring of Nigeria as a nation, this paper provides a searchlight of hope to wriggle out of the socio-political and

SALAHUDEEN Abdul Hameed, Department Of Islamic Studies, School Of Arts And Social Sciences, Osun State College Of Education, Ila-Orangun, Osun State. economic quagmire the nation is immersed. Formulation of policies, structural and fiscal re-engineering and trusting our technologies are not enough if they are not pivoted on sound moral values and spiritual tendencies. In this case, Islamic moral values, ethics and orientations could provide a beacon of lights to realize meaningful restructuring for better and united Nigeria.

\section{What goes wrong in Nigeria?}

There is no gainsaying of the fact that Nigeria as a nation has witnessed and passed through various reforms and restructurings in the past. The major reason for such reforms was to put things in proper shapes and forms. However, the fact remains that the nation has recorded prosperity, progress, deterioration, setbacks, failure and weakness at one time or the other. The successive governments in Nigeria had fixed error of omission, commission, negligence or overbearing on previous governments. Hence, the need to redress or restructure. This is corroborated by the state broadcast of the former Military President, General Ibrahim Gbadamosi Babangida on the occasion of the creation of Akwa Ibom and Kaduna states thus:

When the Military overthrew the last civilian government in December 1983, it did so because that government had ruined the economy of the country, generated national dissention and instability, and had engaged in massive rigging of elections with the attendant violence, insecurity of lives and property. That situation was virtually the same as what obtained early in 1966 when military entered the political arena for the first time (Thompson $1988 ; 10)$

Bearing the ugly situation of Nigeria as a nation in mind, General Ibrahim Gbadamosi Babangida further expressed the reform justification of the military intervention in the governance of Nigeria in September 13, 1987 when he said:

Indeed, the military had taken the reins of government from civilian politicians in December 1983 on account of failure to foster national unity, conduct free and fair elections, eliminate graft and corruption from public life and manage resources in the overall interest of the nation (Thompson !988:11)

In his turn, Major General Muhammadu Buhari (now retired General) on January 1, 1984 advanced his reasons why he toppled the civilian Government of Alhaj Sheu Uthman Shagari and felt the change was necessary because the nation was under 
the heavy burden of economic recession, crisis of confidence, corruption and indiscipline and shirk of constitutional responsibilities in pursuance of fringe benefits, unnecessary foreign travels and pre-occupation with determination of their salary scale (Thompson !988:11)

It is heart-breaking that the ugly situation which made Major General Muhammadu Buhari (1983), General Ibrahim Gbadamosi Babangida and General Sanni Abacha (1994)took over the leadership of Nigeria still persist today. The Government of of President Olusegun Obasanjo pursued and introduced some reforms purportedly to correct some anomalies in governance of Nigeria. His reform agenga gave birth to institutions like Economic and financial Crime Commission (EFCC), Independent Corrupt Practices Commission (ICPC) while President Goodluck Ebele Jonathan introduced Bank Verification Number (BVN) and Treasury Single Account (TSA) all in a bid to stem down corruption and heighten anti-corruption campaigns. We need to note that the through these institutions were and are not conscientiously pursued and common masses have been bearing the brunt of the inadequacies.

Furthermore, Hassan (2011:18) submits that the absence of good governance contributes to the slow but seemingly sure decline of capacity of the Nigerian state to provide peace and security for its citizens. He also opines that corrupt and incompetent government constitutes a significant factor of violence and general insecurity in Nigeria. He attributes the failure in Nigeria to factors which include lack of determination, sound intellect, injustice, perversion of justice, mischief making, deep-seated corruption, bad leadership, greed,ethnic ascendance, geo-political advantage and personal accumulation of wealth.

In his own perception, Anyacho (2002:91)shares belief in the opinions of the late Major Kaduna Nzeogwu and General J.T.U Aguyi Ironsi that the major society's problem was corruption. Nzeogwu believed that the country's enemies are the political profiteers, smidlers, men in high and low places that seek bribes and demand ten-per-cent, those that fee to keep the country divided permanently so that they can remain in office as ministers while Aguyi Ironsi believed that the nation would not progress until government stamps out corruption and dishonesty in our public life with ruthless efficacy to restore integrity and self respect in our public affairs. All these are what go wrong in Nigeria and consequently, the search for restructuring. The fact that the problems are perennial makes it seem that restructuring is a myth in Nigeria.

The incumbent government under the leadership of President Muhammadu Buhari believed to be finting corruption has not done enough to convince Nigerians that his administration is sincerely and genuinely committed to the cause and course.. The events unfolding are antithetical to zero tolerance of Buhari's administration to corruption.

\section{RESTRUCTURING AND POINTS OF CALL IN NIGERIA}

Restructuring according to the Oxford Advanced Learner's Dictionary (2000:1261), connotes organizing something in a new and different way. The word restructuring has become significantly emotive in Nigeria and when situated to the nation's polity, it appeals to the idea of re-federalism, re-organization and reform of the Nigerian Constitutional documents and contents. Restructuring in the nation's polity has to do with settling the contentious issues which appear to be resentment against centralizing tendencies and resistance against alteration of extant fiscal arrangement of the nation. (https://www.vanguardngr.com 6/9/2017). There have been decades of agitations, arguments and counter arguments from different quarters. The proponents of restructuring cling to the belief that the nation is battered and immersed in myriads of socio-political and economic problems because the present structure the nation operates on, is defective and is thus due for an overhaul while the antagonists of the agitation opine that restructuring is not what Nigeria as a nation needs to move forward and cleanse it off the socio-political and economic mess ravaging it to the tap root. As the protagonists see restructuring as a part to prosperity and well-being, the antagonists of it see it as impossibility and creation of strife and tension in the country.

The situation of serious agitations on restructuring and its constituents has led to the emergence of three groups and each group has a mind set on salvaging the country. The first group are the politicians. On the surface, the politicians pretend to support restructuring for the sake of it as it boils down on the need to redesign our constitutional compact to ensure it meets the need of all Nigerians and advance the cause of nationhood, democracy and social progress. They perceived misgiving and bad form in the style of governance manifesting in intolerable imbalance in the federal styructure as currently constituted, imbalance in the appointments and imbalance in the distribution of resources. The critics of this group see the politicians in this category as insincere politicians who seek to promote secessionist and selfish agenda (https://www.google.com, vanguard News of 2/9/2017.

The second group are the conservatives who are vehemently opposed to restructuring but perceived that issues of agitation could be settled through the existing parliament and other institutions of government. They disagreed that there are inconsistencies, mischief and inequalities in 1999 Constitution and whining against marginalization by certain sections of the country, is a dishonest enterprise. This category of people as perceived by some other people, are subjects of anxiety that restructuring would reduce their fortune in governance.

The third group are the patriots who believe there is a genuine case for the restructuring or re-engineering of the existing federal structure. They perceived the imperfect nature of the 1999 Constitution as a product of military oligarchy and therefore long overdue for review and total overhaul.. They also contend that the northern dominated military manipulated the federal constituencies and local governments in a manner that favoured the far north at the expense of the next zones in Nigeria. They also contend that, the distribution of powers and thus fail to respect the principle of subsidiarity and autonomy for state 
and local governments. This group also observed thus, that threat and intimidating symptoms of political decay, disintegration of moral values, hopelessness among youths, nihilistic violence, rampant criminality, kidnapping and culticism, decaying infrastructures, insolvency of majority of the states and collapse of of national consensus regarding our common future are product of forsaken restructuring (https://www,google.com- Vanguard News 2/9/2017

From the foregoing, we can deduce that end is not at sight in respect of arguments, agitations and counter agitations for or against restructuring in Nigeria and hence, the persistence of the perceived problems.

\section{THE NEED FOR RESTRUCTURING IN NIGERIA}

Nigeria actually needs restructuring. The required restructuring to guarantee the well-being and good governance is not as postulated by the three groups earlier discussed. The problems with us in Nigeria as a black nation do not exclusively associate with the stracture, form and manner of governance. It is also tenable that the instrument of governance i.e the constitution might have been due for review but the problems in Nigeria are not characteristically of the constitutional document. The problems are associated with bad leadership. Our leaders in Nigeria are insincere, dishonest, callous, fraudulent, irresponsible, wicked and selfish.

Nigeria is blessed with a lot of potentials which if well managed and administered by a more ethical, transparent and accountable leadership at all levels of governance. Our political leaders only pay lip-service and mar their purported plans by insincerity of purpose, selfishness and morbid desires Jimoh(2011:139), The misgivings, mischief, inconsistencies, inequalities, insincerity and decadence that characterize the socio-political and economic lives of Nigeria as a nation, are as a result of bad, irresponsible, irresonsive, insensitive, fraudulent and unjust leadership and not of physical structure of the country and her fiscal arrangement. Jimoh further opines that good and responsible national leadership is expected to be responsible and responsive to the yearnings and common ideal aspirations of the subjects without any form of bias and prejudice as exemplified by the second khalifatur- Rasul, Umar bn al-Khattab al-Faruqi whose stewardship and statesmanship were characterized by selfless service and sacrifice mirrored by taqwa i.e Fear of God and Consciousness.

In Nigeria, political leaders are seen as representatives of the masses in precept and not in practice. They are selfish, irresponsible and unaccountable. Islam prescribes that leaders have moral and constitutional obligation to serve and be responsible to their people as one of them. Al-Shena(2002:86) submits that the commander of the faithful is one of his people and is most heavy-laden among them. That we have not been getting it right in Nigeria, the reason is not far fetched. It is because the nation actually need restructuring but it is not the kindmost people are actually canvassing for.

The actual restructuring the nation needs is in collective self-examination, assessment, critical change of attitude(negative attitude), and public spirited approach to public administration by the nation's operators of the constitution. The problem of the nation is exclusively not of the constitution, structure of the nation and fiscal arrangement. The problem is of bad leadership spirit, attitude and orientation. Akanni describes the nation's leaders thus:

They are recipients and beneficiaries of the service, obedience, sacrifice and labour of everyone else who is unfortunate to be under them. They themselves are the objects of service. They don't serve but collect the services of all others. Every other man serves their purpose, their ego, their appetite fame---=-

Muslims' democrats according to Abdul Mu'min (2002:19) the Muslims should see themselves, as operating within the provisions of shari'ah which guarantees the absolute supremacy of the law and uncompromising equality before the law and as democratic represntativesw of God, Jimoh (2003), submits that they are charged with the responsibility of overseeing the affairs of the other human beings in their domain.

\section{PlatForm OF ISLAMIC MORAL VALUES AND SUSTAINABLE RESTRUCTURING}

The call points of restructuring in Nigeria among the agitators boil down on power distribution among levels of government to accommodate total federalism as well as fiscal fiscal re-engineering in such a way that each region would have power of control over the resources in their domain. The power should devolve more to the regions, each region should Regional House of Assembly, Court, police and sustain its educational sector and others. All these and others are packaged in the modality for the restructuring of Nigeria as a nation.

However, the packages are not sufficient enough to restructure Nigeria for better performance and change. This is because human factor majorly dictates and underlines positive and sustainable restructuring. Restructuring for good can be achieved through change of attitude, spirited approach to public affairs, self-examination and determination to uphold the ideal. The Qur'an chapter 8:29 says:

$\mathrm{O}$ ye who believe, If you are careful of (your duty to) Allah, He will grant you a distinction and do away with your evils and forgive you; and Allah is the Lord of mighty grace

Restructuring along ethnical, regional and tribal line in Nigeria, is not worthwhile. What is needed is a change attitude. Geo-political demarcation and re-apportioning of resource control can not effectively as change when the rulers would see themselves as mere vicegerents of Allah among their people, see themselves as equal before the, responsible and accountable to their subjects. Ahmad (1977:31) quotes Umar al-Khattab as saying:

I have no authority over the bait al-mal (public treasury) than a custodian has over the property of an orphan. If I would be well-to-do, I would not accept any honorarium; if not, I would draw a little to 
meet the ordinary necessities of life. Brother!

I am your servant and you should control and question my actions. One of these is that public money should neither be unnecessarily hoarded my wasted. I must work for the welfare and prosperity of our people

The following are some of the enviable manners and virtues which if imbibed, would motivate good and responsible governance in Nigeria, solve the ravaging socio-political crises and eventually engender peace and tranquility in the nation:

- Keeping of oaths (Qur'an 5:89)

- Keeping Trusts and Promises (Qur'an 23:8)

- Avoidance of Hate speech (Qur'an 23:3)

- Respect of Treaties (Qur'an 9:4)

- Avoidance of lies (Qur'an 22:30)

- Avoidance of Bribery (Qur'an 27:36)

- Goodwill to others (Qur'an 24:12)

- Avoidance of Deceit (Qur'an 6:152)

- Making Peace among warring People or Groups (Qur'an 49:9)

- Upholding Justice (Qur'an 4:135)

- Avoidance of spread of mischief and false information (Qur'an 49:6)

- Obedience to constituted authority (Qur'an 49:12)

- Leniency and meaning consultation in governance (Qur'an 3:159)

- Avoidance of Fraud and corruption (Qur'an 4:29)

The above cited verses of Qur'an are few moral and attitudinal recipes towards good and responsible governance, peaceful co-existence and monumental development in Nigeria.

\section{CONCLUSION}

There is no gainsaying of the fact that the crisis of corruption, mismanagement of the common wealth, administrative infractions and impunities, greed, egoistic tendencies, tribalism, nepotism and selfishness that plaque Nigeria as a nation, are neither constitutionally nor structurally induced. The simple reasons are bad leadership and followership. Our leaders lack the fear of God in running our affairs, public spirited approach to service and sincerity of purpose while followers too are not patriotic.

\section{REFERENCES}

[1] Abdul-Rahman al-Shena(2002), The Message of Islam, Riyadh, n.p

[2] Abdul-Salam Abdul-Mu'min (2002), Shari'ah and the Solution to th Problems Facing the Administration of Justice in Nigeria, Lagos, Ad-Da'awah al-Islamiyyah Book Centre.

[3] Anyacho, E.O, (2002), Corruption and National Development: Examination of the Roles of Religion in Curbing Corruption in Nigeria, (Gbola Aderibigbe andDeji Ayegbogbon eds), Religion, Globalization, Science and Technology, Ijebu-Ode, National Association for the Study of Religion and Education (NASRED)

[4]Hassan, I.H (2011), "Violence in Nigeria: Understanding the Role of Leadership from Fodio's Diya Ahl- Rashad" in al-Ijtihad, The Journal of the Islamization of Knowledge and Contemporary Issues, Kano, The International Institute of Islamic Thoughts (IIIT), vol.9 (i)

[5] Jamil, A (1977), The Hundred Great Muslims, Lahore, Ferozsons ltd.
[6] Jimoh, L. A (2003), Ensuring Socio-Political Stability in Nigeria on the Wheel of Religion, A paper presented at the $24^{\text {th }}$ Annual National Conference of the National Association for Study of Religions (NASR), Between $7^{\text {th }}$ and $11^{\text {th }}$ October, 2003 at the Department of Religions, University of Ilorin, Ilorin.

[7] Jimoh, L.A (2011), "The Example of Umar Bn al- Khattab's Leadership: Lessons for Nigerian Political Leaders" in al-Ijtihad, The Journal of the Islamization of Knowledge and Contemporary Issues, Kano, The International Institute of Islamic Thoughts (IIIT), vol.9 (i)

[8] Thompson, T (1988), Fractured Jail Sentence, Enugu, Fourth Dimension Publishing Co. Ltd. 